\title{
The effect of memantine on cerebral cortex tumor necrosis factor alpha exression in a rat model of acute hyperammonemia
}

\author{
Stergios Tsartsalis ${ }^{1 *}$, Constantinos Tomos ${ }^{1}$, Theodora Karanikola ${ }^{2}$, Maria Mironidou-Tzouveleki ${ }^{1}$ \\ From $1^{\text {st }}$ International Congress on Neurobiology and Clinical Psychopharmacology \\ and European Psychiatric Association Conference on Treatment Guidance \\ Thessaloniki, Greece. 19-22 November 2009
}

\section{Background}

Literature suggests that proinflammatory mechanisms are implicated in the pathophysiology of hepatic encephalopathy. This is mainly caused by high circulating levels of ammonia (hyperammonemia-HA), due to liver failure [1,2]. In addition, NMDA receptors are excessively activated during acute hyperammonemia and thus significally contribute to the brain damage [3]. In fact, blockage of this receptor type is beneficial in experimental models of acute hyperammonemia [3,4]. The aim of this study is to assess the effect of memantine, a noncompetitive NMDA receptor antagonist, on the expression of tumor necrosis factor alpha (TNF- $\alpha$ ), a major proinflammatory cytokine, in the brain of a rat model of acute hyperammonemia.

\section{Materials and methods}

HA was induced in male Wistar rats by two consecutive ammonium acetate intraperitoneal (i.p.) injections of 12 and $8 \mathrm{mmol} / \mathrm{kg}$ respectively [2]. Another group of rats received memantine hydrochloride $(20 \mathrm{mg} / \mathrm{kg}) 30 \mathrm{~min}-$ utes before the first ammonium acetate injection, while control group received saline i.p. Rats were decapitated 30 minutes after the last injection and cerebral cortex TNF- $\alpha$ expression was determined with reverse transcription quantitative PCR.

\section{Results}

TNF- $\alpha$ expression in rat cerebral cortex was significantly elevated while the administration of memantine hydrochloride diminished its expression.

\section{Conclusions}

Memantine manages to compensate the induction of TNF- $\alpha$, a major proinflammatory cytokine, by acute HA, in the cerebral cortex of rats. Further research is needed in order to determine if the effect of memantine may be attributed to the blockage of NMDA receptors and if it has a similar impact on the expression of other proinflammatory cytokines.

\section{Author details}

${ }^{1} \mathrm{~A}$ ' Laboratory of Pharmacology, Medical School, Aristotle University of Thessaloniki, Greece. ${ }^{2}$ Department of Alveolar Surgery, Implantology and Radiology, Dental School, Aristotle University of Thessaloniki, Thessaloniki, Greece.

Published: 22 April 2010

\section{References}

1. Jiang W, Desjardins P, Butterworth RF: Direct evidence for central proinflammatory mechanisms in rats with experimental acute liver failure: protective effect of hypothermia. I Cereb Blood Flow Metab 2009, 29(5):944-952.

2. Singh S, Koiri RK, Trigun SK: Acute and chronic hyperammonemia modulate antioxidant enzymes differently in cerebral cortex and cerebellum. Neurochem Res 2008, 33(1):103-113.

3. Rodrigo R, Cauli O, Boix J, ElMlili N, Agusti A, Felipo V: Role of NMDA receptors in acute liver failure and ammonia toxicity: therapeutical implications. Neurochem Int 2009, 55(1-3):113-118.

4. Kosenko E, Kaminski Y, Lopata O, Muravyov N, Felipo V: Blocking NMDA receptors prevents the oxidative stress induced by acute ammonia intoxication. Free Radic Biol Med 1999, 26(11-12):1369-1374.

\section{doi:10.1186/1744-859X-9-S1-S181}

Cite this article as: Tsartsalis et al:: The effect of memantine on cerebral cortex tumor necrosis factor alpha exression in a rat model of acute hyperammonemia. Annals of General Psychiatry 2010 9(Suppl 1):S181. 